Nature of fuid withdrawn.-This was examined on several occasions and showed little variation from the analysis given. (1) Appearance: Milk-like, with no separation into a creamy layer on standing, and little or no tendency to clot. In first aspiration blood was present, but in later ones none was detected. (2) Specific gravity: 1008-1016. (3) Reaction: Alkaline. (4) Fat: Nil. (5) Albumin: Very abundant. (6) Micro-organisms: None detected either in smears of fluid or by culture. (7) Cellular content: Practically entirely composed of small lymphocytes. No filaria found. Some of the fluid was sent to Surgeon Captain BassettBmith, who confirmed the above findings, and kindly inoculated a guinea-pig with it. The animal was killed after a month's time and showed no signs of tubercle.

Result of autopsy.-Subject was thin; extreme emaciation not present. The right pleural cavity contained much chyliform flaid similar to above. The pleura itself was slightly injected; in places a little fibrinous deposit. The right lung was slightly collapsed, but floated in water; no pathological change on section. Some thickening of pleura close to spine at level of seventh, eighth, and ninth thoracic vertebræ (possibly due to original trauma); no injury to thoracic duct found. The heart, left lung, and all abdominal organs were quite healthy ; no neoplasm or tumour of any sort found either in thorax or abdomen. Microscopic sections of right lung, pleura, and of patch of thickened pleura close to spine were made; no tubercular lesions found. This was confirmed by Surgeon Captain BassettSmith, to whom parts of these tissues were sent.

Remarks on the Differential Diagnosis.

The chief points of interest about this case are the large quantity and peculiar characteristics of the fluid removed. The exact determination of the lesion (whether pathological or traumatic, or both) presented great difficulty. With the history of trauma and milky fluid in the pleural cavity, one is inclined to attribute the condition to injury of the thoracic duct. Against this are the post-mortem findings, the nature and excessive amount of the fluid. Also there were no marked signs of the wasting or symptoms of thirst usually associated with this lesion. Tuberculosis is occasionally responsible for chyliform effusions with characteristics similar to those in the present case, but in view of the complete absence of any tubercular lesions had to be abandcned.

The blood count throws no apparent light on the condition. It was as follows: R.B.C., 3,420,000. W.B.C., 13,800. Differential count, neutrophils, 70 per cent. ; large Iymphocytes, 8 per cent. ; small lymphocytes, 12 per cent.; and mononuclears, 9 per cent. Blood platelets increased, no filaria were found. Neoplasm is also associated with pleural exudates of this type and has been excluded.

The not very extensive literature on this subject has not been available. Simon, in "Clinical Diagnosis," states that chyloid and chylous exudates have been repeatedly observed. Out of 104,49 occurred in the pleural cavity. The causes given were pressure on the thoracic duct, tumours, syphilitic disease of the liver, disease of lymph vessels, and Hodgkin's disease. He also mentions that some chyloid exudates contain no fat. In chylous ascites, Quincke recognises two types, one in which there is a true fatty fluid, the other in which the turbidity is due to chemical substances of a nonfatty nature: lecithins combined with globulins. Milton ${ }^{2}$ has reported a case in which 15 pints of chylous fluid were withdrawn from the left pleural cavity at one sitting. This fluid contained fat, a few cocci, but no tubercle bacilli. The fluid did not recur and the patient made a good recovery. He attributed the effusion to tuberculosis of the thoracic duct.

In conclusion, we wish to thank Surgeon Captain P. W. Bassett-Smith, C.B., C.M.G., R.N., for his kindness in confirming the pathological findings and Surgeon Commander T. W. Philip, R.N., for permission to publish the case.

\section{CASE OF INTESTINAL OBSTRUCTION BY MECKEL'S DIVERTICULUM.}

By R. Altuan Bennetw, M.B. Lond., M.R.C.S. MEDICAL OFFICER IN CHARGE OF ELECTRICAL DEPARTMENT, TORBAY HOSPITAL, TORQUAY.

THE following case of intestinal obstruction presents points of interest.

Pationt, a girl of 13, was admitted on Nov. 21st, 1918 ander the care of Dr. A. Spong, with the history that

\footnotetext{
1 Brit. Med. Jour., November, 1907.
}

four days earlier she was taken, after a bearty meal, with sudden pain in the abdomen-not intense pain and not localised, though " perbaps worse at first in the right flank." Soon after the pain started she vomited and had been more or less sick ever since; the last vomit was copious, black and evil-smelling. Since the attack began the bowels had not acted, nor had any flatus passed up or down.

On admission patient was dull and heavg, but did not look like an acute abdominal case; T. $98.6^{\circ}$ F., P. 128, R. 24. The tongue was furred. The whole abdomen was rigid, but not excessively so; tender, but not acutely. Pain was felt most on the left side, just above the umbilicus, but when asked to point to the worst place she passed her hand impartially over the whole abdominal wall. There was just a suspicion of visible peristalsis once in the left hypochondrium; the rectum was empty.

A diagnosis of intestinal obstruction was made and the abdomen was opened at once. Distended and acutely congested small bowel presented, and, when pusbed aside, revealed collapsed small intestine and colon. During the manipulation the collapsed bowel slowly filled with flatus, and it was evident that, whatever the cause of the obstruction, the handling had relieved it. After some searching a Meckel's diverticulum was found. The proximal portion was a thin fibrous cord twisted many times on its axis; the distal part was a dilated pouch, inflamed and full of blood clot, and adberent to a tag from the great omentum, also inflamed and twisted. This connexion had formed an arch or band under which the lower 4 feet of the ileum had become partially strangulated.

The band was divided close to the bowel and again just above the dilated pouch. The proximal end was buried by a purse-string suture; the distal end was tied off in the usual way. The wound was not drained.

Nov. 29th : Patient had done very well; the bowels acted freely with a simple enema on the third day; no temperature or bad symptoms of any kind.

\section{NOTES ON A CASE OF CENTIPEDE BITE.}

By STEPHEN W. CoffiN, M.R.C.S., L.R.C.P., CAPTAIN, R.A.M.C. (T.C.).

THE following case of the results of a centipede bite seems worthy of record :-

The patient, a native Christian, aged 22, reported sick on Dec. 30 th, 1918, with a history of having been bitten on the scrotum about midnight by a centipede. He said he actually saw the insect biting him and knocked it off; considerable pain immediatelv; an hour or so later vomited twice. When first seen (about 7.30 A.M.) the left cremaster was contracted and the scrotum very wrinkled, but neither swollen nor murkedly tender. He said it felt hot. Patient was put to bed, purged, and the scrotum fomented. Later in the day the following condition, stated to have commenced in the morning soon after first examination, was found. There were several large bullæ on the scrotum containing serum, which showed no cells or other structure microscopically, and proved sterile on cultivation. Over the chest, neck, and arms was a papular and yesicular eruption, at each hair follicle, giving an appearance of cutis anserina. Temperature $99^{\circ}$ F., pulse 80 ; he felt fairly well. Trace of albumin in the urine.

On the second day pulse and temperature were as before, some pain over area of rash, and aching in scrotum. The bullæ on scrotum had broken; almost whole scrotum raw and denuded of skin. No testicular tenderness. The skin eruption was composed of a few papules and a large number of vesicles about $1 \mathrm{~mm}$. in diameter, each surrounded by real areola. Each lesion coincided with a hair follicle, the hair growing from the centre of each vesicle.

Distribution: Very marked on both sides of the chest, over shoulders and arms, and on neck and face. In the last two places the vesicles were very small and numerous. The ears were thickly covered; vesicles confluent over pinnæ, forming bullæ. The antarior and inner surfaces of the thighs, especially over Scarpa's triangle, were well covered. The rash was less marked over front of chest and abdomen, in popliteal spaces, on forehead, between scapulæ, and on forearms and legs. No eruption over pressure points (e.g., buttocks, back-except between scapulæ-and back of legs and thighs). The feet and palms of hands were free; a few vesicles on dorsum of hands. No spots in the mouth. A vesicle on an ear and one on a shoulder were opened, and yielded a muco-purulent fluid contrining a few leucocytes and mucus. It was sterile on cultivation.

On the third morning the temperature was normal ; $99^{\circ}$ in evening; the surface of the scrotum was as before, but the vesicles on the face, neck, chest, and arms had reverted to a papular condition withont any encrusting. By the evening of the third day vesicles remained only in the axillæ and on upper portions of anterior and inner surfaces of both thighs. 